\title{
The effectiveness of new 3D visual effect speed hump in speed reduction
}

\author{
Kamarudin Ambak ${ }^{1, *}$, Suhailah Jemari ${ }^{1}$, Basil David Daniel ${ }^{1}$, Mohd Hanifi Othman, and \\ Muhamad Nazri Borhan ${ }^{2}$ \\ ${ }^{1}$ Smart Driving Research Center, Faculty of Civil and Environmental Engineering, Universiti Tun \\ Hussein Onn Malaysia, 86400 Batu Pahat, Johor, Malaysia. \\ ${ }^{2}$ Sustainable Urban Transport Research Center, Faculty of Engineering and Built Environment, \\ Universiti Kebangsaan Malaysia, 43650 UKM Bangi, Selangor, Malaysia
}

\begin{abstract}
Intersection is a function of parsing and altering traffic movement. The safety of vehicle manoeuvres at the junction depends on the minimum speed. The purpose of this study is to identify the effectiveness of the usage of temporary speed hump (3D visual effect) to reduce vehicles speed approaching a Priority Junction. This study was conducted at three (3) different residential locations namely Taman Murni, Kampung Merdeka and Taman Bahagia Koperasi in Batu Pahat area. These intersections were chosen because it connects one housing area to another and acts as a short-pass to a destination. Based on the observational activity, there were some traffic conflicting and potential for accidents at the intersection as well. The speed data were collected using laser guns and filled into special forms including date, location, weather, start and end time of observation and also the category of vehicles passed through the intersection. A hypothesis test was conduct to analyze the vehicle speed data before and after installation of the temporary a new 3D visual effect of speed hump. The results were analyzed using the ChiSquare test in Statistical Package for Science Social (SPSS) software. The Chi-Square analysis demonstrates that the effectiveness of using temporary a new 3D visual effect of speed hump is significant statistically $(\mathrm{p}<0.05$, $\left.\chi^{2}==291.575\right)$. Majority vehicles $(74 \%)$ were complied with speed limit when approaching intersection compared to $26 \%$ of vehicles who do not to do so. In addition, there was decline in the number of uninterrupted vehicles can be seen after parking traffic. Therefore, the study confirmed that drivers who speeding over the speed limit zones before approaching the intersection might be intervened after the installation of the new 3D visual effect of speed hump.
\end{abstract}

\section{Introduction}

The development of the nation and increment of population are parallel to the rapid growth of urban areas and the use of traffic on roads. Almost the entire life of the population is not spared from the need for transportation, such as cars, motorcycles and other transportation.

*Corresponding author: kamardin@uthm.edu.my 
Roads are important for users to make their way to the comfort of roads and developers facilitate transport and contribute to smooth traffic. However, the transportation is very much related to the accident if traffic on the road is not properly controlled.

Increased traffic volume and vehicle speed on the road contributed to the traffic congestion rate increase [1]. Driver failure in compliance with rules on road contributes to the potential for accidents [2]. The intersection is a change of route path, where the driver needs to decide on the route change. The decision to change the route of the passage is a great potential for an accident [3]. The data released by PDRM [1] is the highest number of fatalities for drivers' faults that exceed the limits or drive speed. The number of drivers killed in the turning in and out of junction negligence also shows a high number to explain unsafe conditions for a road condition involving intersections. Therefore, to mitigate this problem, remedial methods through engineering approach to a good practice strategy. The strategy focuses on safety traffic operation at a priority intersection area such as the stop/giveway rules at the intersection with the proper installation of the Traffic Calming such as a speed hump.

The use of traffic calming (i.e speed hump) is a traffic control method that helps improve road safety. There are four main objectives of traffic deliberation: improving road safety, providing road space from motor vehicles for walking, improving the comfort of mobility for other road users and reducing traffic congestion [4]. This study covers the assessment of the effectiveness in reducing the speed of vehicles at the crossroads using a new 3D visual effect speed hump. Where the 85th percentile rate of vehicles passing through the area studied were analysed before and after installation of as temporary traffic calming (the 3D visual speed hump) at the selected junctions. Thus, to ensure the vehicles will comply with speed limit and in respect with stop/giveway sign at a priority intersection.

\section{Material and Methods}

The observation on strategic location selection depends on the goals and objectives to be achieved. The steps that need to be taken into account include the use of data retrieval methods and the use of engineering methods used in reducing vehicle speeds. Data retrieval research should use systematic methods and tools that assist in achieving accurate data. The study was conducted involving three different intersections to obtain different profiles for analysis. Traffic utilization is used to obtain comparisons of data in identifying the effectiveness of the method used in reducing the speed of the vehicle at the crossroad.

\subsection{Location of Study}

The intersection is an intersection involving minor and major roads for entry exits in a residential park area in Batu Pahat, District. The intersections involved are:

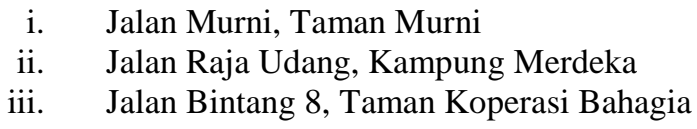

\subsection{Data Collection}

The Data collection was conducted from 9.00 am to $12.00 \mathrm{pm}$ within 3 hours and took 3 days to obtain 1500 samples for each type of vehicle at each location. The data obtained of 
the difference in number of vehicles that did not stop at the intersection before and after putting the traffic calming were then analyzed.

\subsection{Installation of 3D Visual Effect Speed Hump}

The speed data of the vehicle was collected on the condition before and after putting a temporary traffic calming, a speed hump (3D visual effect). The design of a 3D speed hump sticker measuring $3.5 \mathrm{~m}$ length $\mathrm{x} 0.6 \mathrm{~m}$ width is selected and designed to be used as a temporary traffic changer for the route of the study area. The installation of the $3 \mathrm{D}$ visual effect of speed humps as shown in Figure 1. The data obtained is completed into the completed form of the study including date, location, weather, start and end time of observation also the categories of vehicles through the intersection include cars, motorcycles, vans and other commercial vehicles such as light trucks.

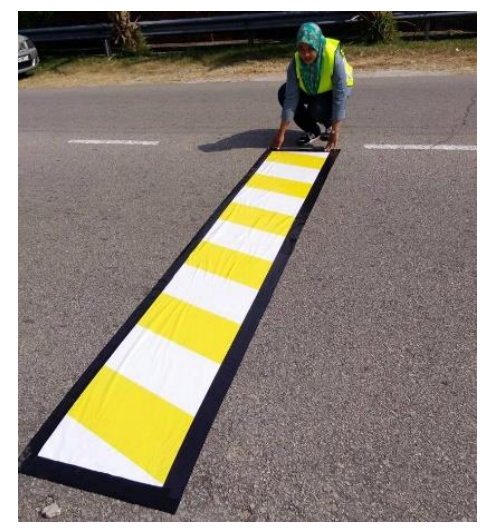

Fig. 1. Installation of the $3 \mathrm{D}$ visual effect speed hump.

\section{Results and Discussions}

The intersection of the Murni road is used as control location because the location had already used speed hump. The collection of speed data before and after the installation of 3D effect speed hump was conducted at Jalan Raja Udang and Jalan Bintang 8.

\subsection{Analysis of Vehicles speed at Jalan Murni (Taman Murni)}

Table 1 shows that the average speed of motorcycles is the highest in other types of vehicles at $22.45 \mathrm{~km} / \mathrm{h}$. However, this speed does not exceed the speed limit when approaching the intersections. The percentile speed for all vehicles passing through Jalan Murni is $27 \mathrm{~km} / \mathrm{h}$. This speed is to represent the $85 \%$ speed of the vehicle passing through the road. The standard deviation of all types of vehicles is between $3.59 \mathrm{~km} / \mathrm{h}$ and $4.61 \mathrm{~km} / \mathrm{h}$. Maximum speed limit on Jalan Murni is a motorcycle with speed exceeding the specified limit of $39 \mathrm{~km} / \mathrm{h}$. Figure 4.2 shows a graph of cumulative percentages of frequencies at Jalan Murni, Taman Murni. 
Table 1 Vehicles Speed at Jalan Murni Taman Murni $(n=1500)$.

\begin{tabular}{cccc}
\hline Classification of Vehicle & Motorcycle & Car & Van/Light Truck \\
& & Speed $(\mathrm{km} / \mathrm{h})$ & \\
Mean Speed & 22.45 & 21.79 & 19.40 \\
$85^{\text {th }}$ Percentile & 26.50 & 24.50 & 23.00 \\
Standard Deviation & 4.61 & 3.79 & 3.59 \\
Maximum Speed & 39 & 31 & 26 \\
\hline
\end{tabular}

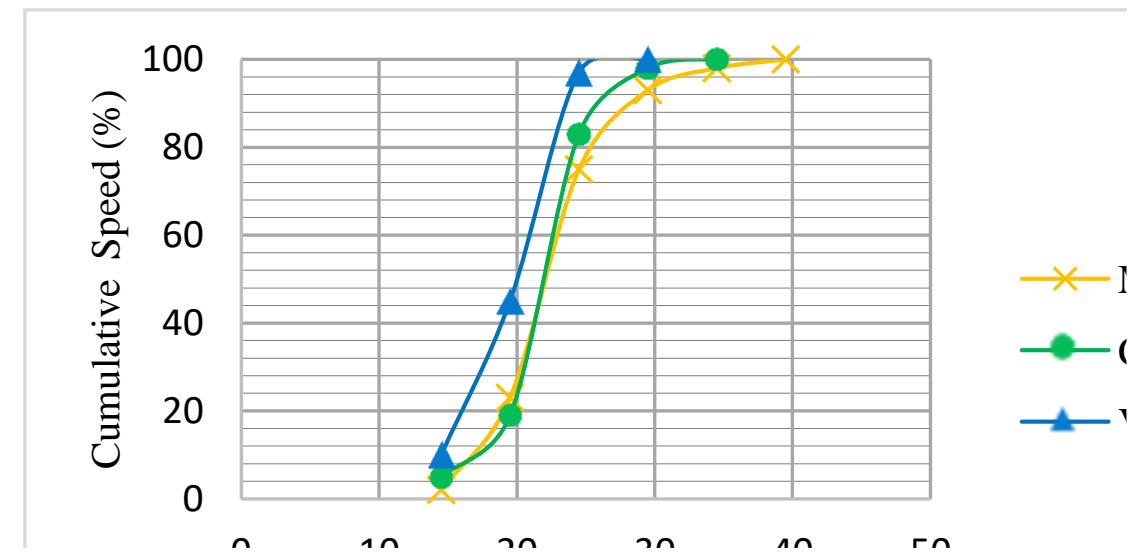

Fig. 2. Cumulative speed percentage at Jalan Murni.

\subsection{Analysis of Vehicles speed at Jalan Raja Udang (Kg. Merdeka)}

Table 2 shows the differential speed after placing the temporary traffic (3D visual effect speed hump). Average car speed showed the highest value of $40.65 \mathrm{~km} / \mathrm{h}$ compared to two other types of vehicles that each are $39.30 \mathrm{~km} / \mathrm{h}$ and $35.45 \mathrm{~km} / \mathrm{h}$ respectively. The average car speeds are reduced to $29.80 \mathrm{~km} / \mathrm{h}$ and $27.90 \mathrm{~km} / \mathrm{h}$ and $29.25 \mathrm{~km} / \mathrm{h}$ respectively for motorcycles and vans after the placing. The $85^{\text {th }}$ percentile speed for all vehicles passing Jalan Raja Udang, Kampung Merdeka before is $45 \mathrm{~km} / \mathrm{h}$ and after is $34 \mathrm{~km} / \mathrm{h}$. This speed is to represent the $85 \%$ speed of the vehicle passing through the road. The standard deviation of all types of vehicles is between $4.25 \mathrm{~km} / \mathrm{h}$ and $5.75 \mathrm{~km} / \mathrm{h}$ for before and $5.04 \mathrm{~km} / \mathrm{h}$ until $5.48 \mathrm{~km} / \mathrm{h}$ for after. The maximum speed limit on Jalan Raja Udang is a motorcycle with a speed exceeding the prescribed limit of $60 \mathrm{~km} / \mathrm{h}$ and a decrease after the placing traffic calming to $42 \mathrm{~km} / \mathrm{h}$. Figure 3 and Figure 4 shows a graph of cumulative percentages of frequencies against speed limits at Jalan Raja Udang, Kampung Merdeka.

Table 2 : Vehicles Speed at Jalan Raja Udang, Kampung Merdeka ( $\mathrm{n}=1500)$.

\begin{tabular}{lcccccc}
\hline & \multicolumn{2}{c}{ Motocycle } & \multicolumn{2}{c}{ Car } \\
Speed $(\mathbf{k m} / \mathbf{h})$
\end{tabular}

( ) after installed a 3D visual effect speed hump 


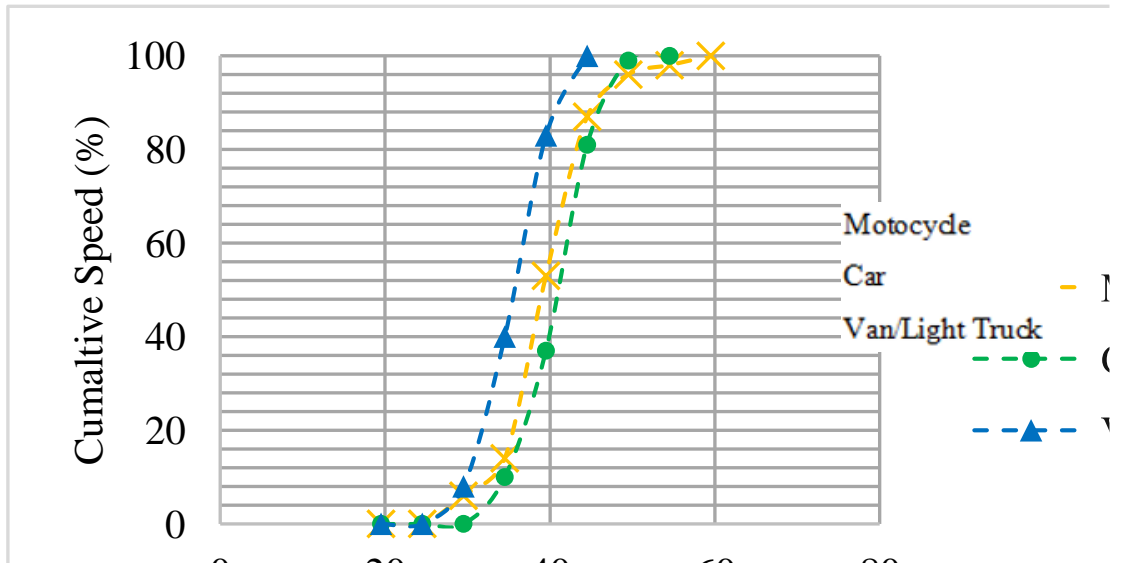

Fig. 3. Cumulative speed percentage before at Jalan Raja Udang, Kampung Merdeka.

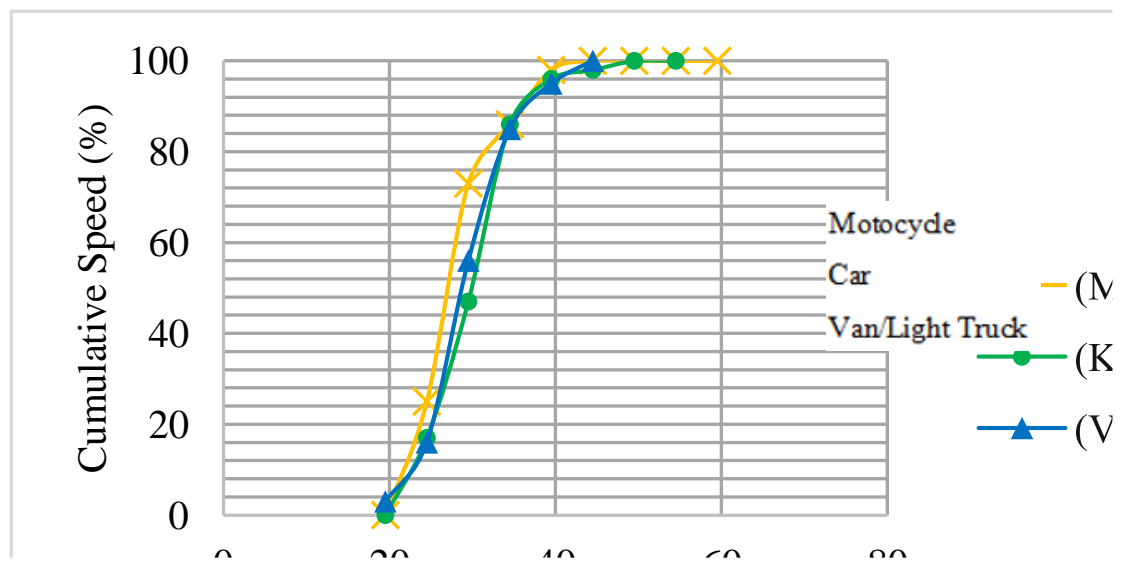

Fig. 4. Cumulative speed percentage after at Jalan Raja Udang, Kampung Merdeka.

\subsection{Analysis of Vehicles speed at Jalan Bintang (Taman Koperasi Bahagia)}

Table 3 shows a slightly different mean speed after the 3D visual effect speed hump. The average speed of three types of vehicles passing through the road is within $28 \mathrm{~km} / \mathrm{h}$. The average speed drops to $26 \mathrm{~km} / \mathrm{h}$ after placing traffic calming. The $85^{\text {th }}$ percentile speed for all vehicles passing Jalan Bintang 8, Taman Koperasi Bahagia before the installation is $34.5 \mathrm{~km} / \mathrm{h}$ and after is $32 \mathrm{~km} / \mathrm{h}$. This speed is to represent the $85 \%$ speed of the vehicle passing through the road. The standard deviation of all types of vehicles is between $6 \mathrm{~km} / \mathrm{h}$ and $7 \mathrm{~km} / \mathrm{h}$ for before and $6.1 \mathrm{~km} / \mathrm{h}$ until $6.5 \mathrm{~km} / \mathrm{h}$ for after. The maximum speed limit on Jalan Bintang 8 is a motorcycle with a speed of $46 \mathrm{~km} / \mathrm{h}$ and a slight decrease after placing to $42 \mathrm{~km} / \mathrm{h}$. Figure 4.4 and Figure 4.5 show a graph of cumulative percentages of frequencies against speed limits at Jalan Bintang 8, Taman Koperasi Bahagia. 
Table 3 Vehicles Speed at Jalan Bintang 8, Taman Koperasi Bahagia $(n=1500)$.

\begin{tabular}{ccccccc}
\hline & \multicolumn{2}{c}{ Motocycle } & \multicolumn{3}{c}{$\begin{array}{c}\text { Car } \\
\text { Speed } \mathbf{k m} / \mathbf{h})\end{array}$} \\
\hline & & & & & \\
Mean Speed & 27.85 & $(26.75)$ & 27.9 & $(26.90)$ & 27.55 & $(25.95)$ \\
$85^{\text {th }}$ Percentile & 33.00 & $(32.50)$ & 34.50 & $(33.00)$ & 33.00 & $(32.00)$ \\
Standard Deviation & 5.99 & $(6.17)$ & 6.33 & $(6.55)$ & 7.00 & $(6.41)$ \\
Maximum Speed & 46 & $(42)$ & 43 & $(41)$ & 45 & $(40)$ \\
& & & & & & \\
\hline
\end{tabular}

( ) after installed a 3D visual effect speed hump

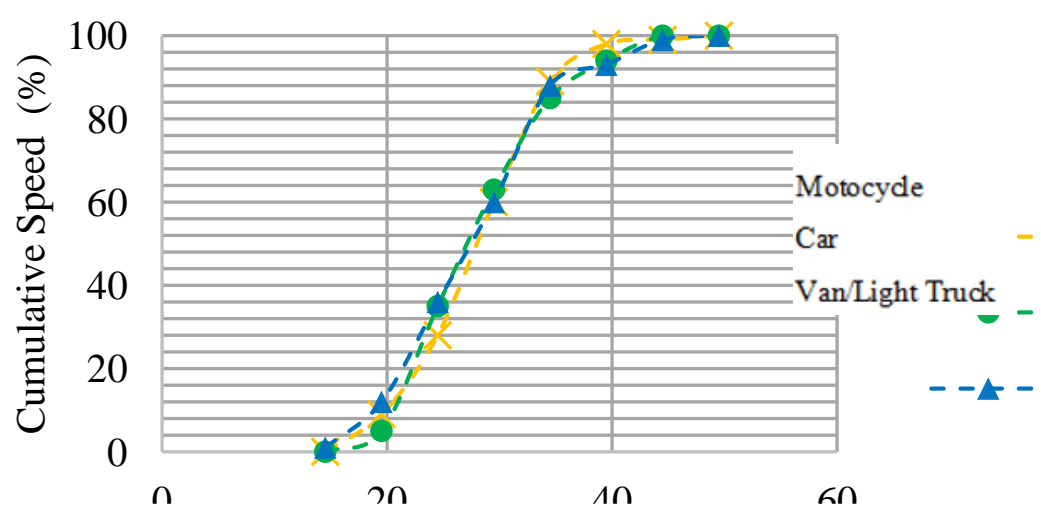

Fig. 5. Cumulative speed percentage before at Jalan Bintang 8, Taman Koperasi Bahagia.

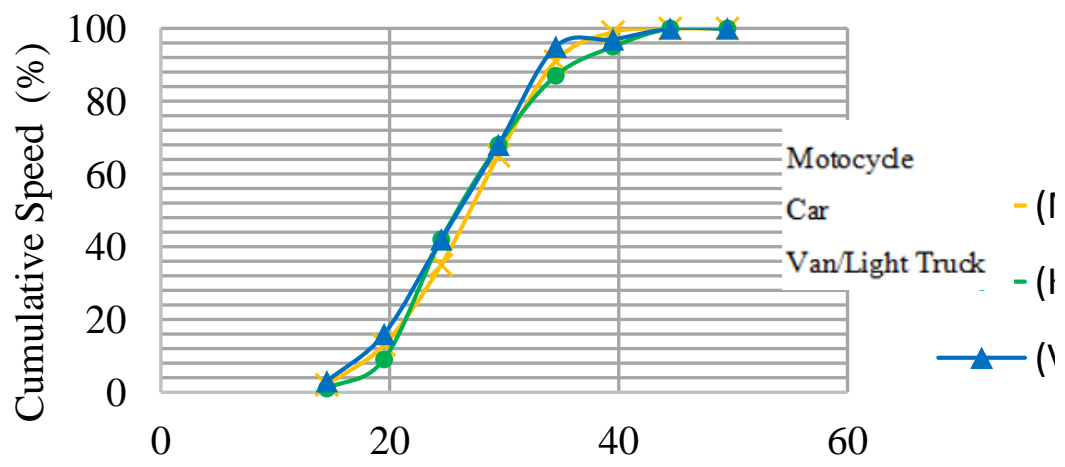

Fig. 6. Cumulative speed percentage after at Jalan Bintang 8, Taman Koperasi Bahagia.

\subsection{Frequency of Vehicles Do Not Stop at Junction}

Figure 6 shows the results of the observation data made at the selected intersections. The motorcycles in Jalan Murni show the highest value of 22 from the total number of samples taken. While, there are 15 vehicles for cars and vans and light trucks.

The location of the Jalan Raja Udang shows the difference in frequency of vehicles that does not stop at the crossroads for the situation before and after the installation of 3D visual effect speed hump. The observation was conducted with a total of 58 motorcycle frequencies, 40 cars and 20 van or light truck that did not stop the vehicle before the $3 \mathrm{D}$ 
visual effect speed hump calming was installed. Whereas after the installation, the analysis shows there are significant reduction in the frequency. Whereas many as 22 frequency variations are reduced for motorcyclists, 12 frequencies for car users and only 5 for van users and light trucks.

Subsequently, the difference in frequency of vehicles that did not stop at the Jalan Bintang 8 junction of 36 motorcycles frequency, 33 for car vehicles and 19 for van or light truck that did not stop the vehicle before 3D visual effect speed hump was placed. Whereas after the installed the 3D visual effect speed humps the observation data shows the reduction of vehicle frequency. Where as many seven times variations are reduced for motorcyclists, five times for car users and only seven for van users and light trucks.

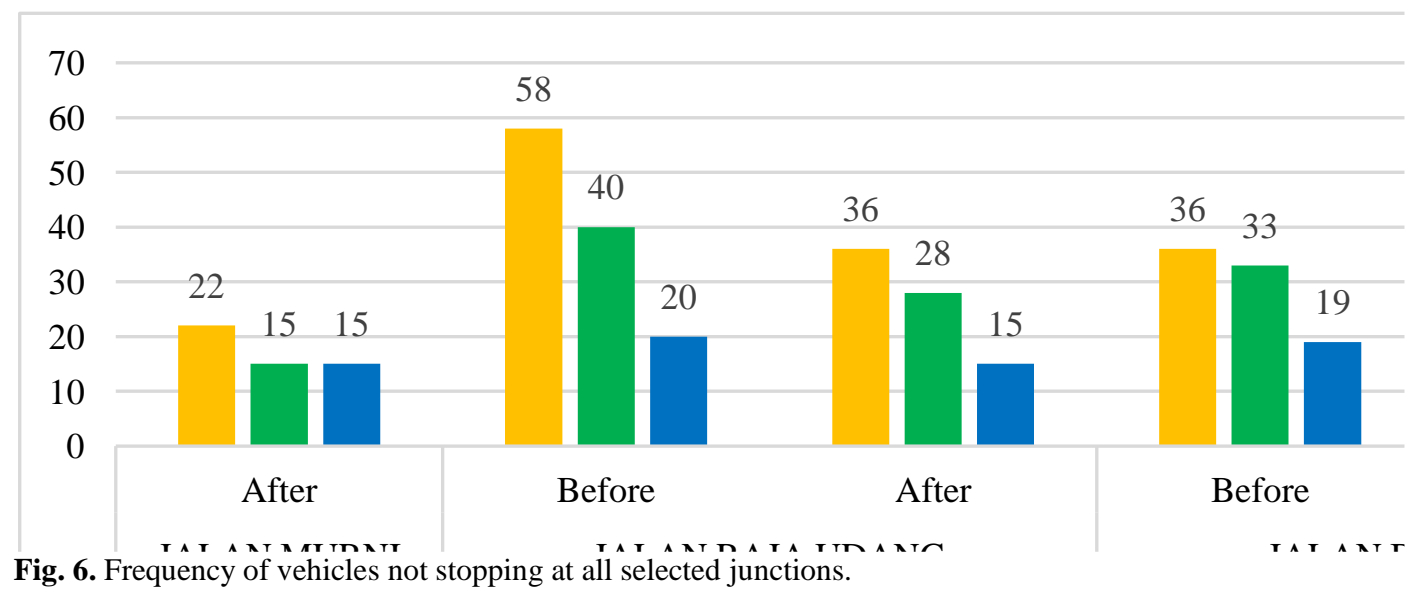

Fig. 6. Frequency of vehicles not stopping at all selected junctions.

\subsection{Chi-square Test}

The relationship of the vehicle speed limit is from the factor of the traffic flow variable while there are external factors that affect the speed and can be seen through this test. It is the location of the intersection and the type of vehicle involved.

Table 4 shows the results of the situation before placing the installation of $3 \mathrm{D}$ visual effect speed hump is $73.4 \%$ of vehicles that do not comply with the speed limit compared to the condition after the installation are $26.6 \%$. The chi-square test showed significantly effective $\left(\chi^{2}=291.575, \mathrm{p}=0.000\right)$ that the presence of traffic calming before the intersection is an effective vehicle speed reduction method. In controlling traffic, engineering traffic is used to reduce the speed and volume of traffic within residential and commercial areas [5].

The effect of 3D factors generated on temporary traffic distributors has given rise to the condition of the drivers as they arise and confuse drivers through it. The driver's situation that pressed the brake when approaching the bicycle proved that the driver was convinced there was a physical barrier on the road surface. In a report on the Transport Engineer Institution (ITE) and the Federal Highway Administration [6] states that traffic reversals a matter of change in the road alignment that physically affects the vehicle through it. Next steps to reduce the speed of traffic and the amount of deductions can be reduced in the interests of road safety, vitality and other public purposes. 
Table 4 Chi Square Test between speed limit and speed hump/3D visual $(\mathrm{n}=1500)$.

\begin{tabular}{cccr}
\hline Speed Limit & \multicolumn{2}{c}{ Situation } & Total \\
\hline Before & After & \\
Comply & $275(26.0 \%)$ & $782(74.0 \%)$ & $1057(100 \%)$ \\
Not Comply & $325(73.4 \%)$ & $118(26.6 \%)$ & $443(100 \%)$ \\
\hline$\left(\chi^{2}=291.575, \mathrm{df}=1, \mathrm{p}=0.000\right)$ & &
\end{tabular}

Table 5 shows the difference between the location of the Jalan Raja Udang and Jalan Bintang 8 intersection with a more than half $(56.7 \%)$ and $42.7 \%$, compared with only $0.6 \%$ Jalan Murni Intersection. Speed limit for a vehicle depends on the geometric state of an area [7]. The chi-square test showed significantly proof $\left(\chi^{2}=162.096, p=0.000\right)$ that the speed limit impediments at Jalan Raja Udang and Jalan Bintang 8 intersection due to the absence of traffic calming to reduce the speed of the vehicle before approaching the intersection. Installation of the hump on the road has an effective effect in reducing the speed of the vehicle passing through it [8]. This situation explains the relationship between the speed humps on a road surface to reduce the speed of the vehicle. Sherbrooke City and University Sherbrooke proved that the existence of a speed hump caused a discomfort to the driver and speed humps on the road has an effective effect in reducing the speed of the vehicle through it [10]. The statistical from previous analysis obtained the difference in velocity data before and after the installation of bumps [11]. This situation explains the relationship between the speed humps on a road surface to reduce the speed of the vehicle.

Table 5 Chi Square Test between speed limit and intersection location before $(n=1500)$.

\begin{tabular}{ccccc}
\hline Speed Limit & \multicolumn{3}{c}{ Intersection Location } & Total \\
\hline & Jalan Murni & Jalan Raja & Jalan Bintang \\
& & Udang & 8 \\
Comply & $297(28.0 \%)$ & $349(33.0 \%)$ & $411(39.0 \%)$ & $1057(100 \%)$ \\
Not Comply & $3(0.6 \%)$ & $251(56.7 \%)$ & $189(42.7 \%)$ & $443(100 \%)$ \\
\hline
\end{tabular}

$\left(\chi^{2}=162.096, \mathrm{df}=2, \mathrm{p}=0.000\right)$

Table 6 shows that the results of the van and light truck compliance were $36 \%$ compared to other types of vehicles. However, the non-compliance of speed limits for motorcycles and cars is high at $35.4 \%$ and $37.7 \%$ respectively. The difference in the characteristics of the vehicle in the design, the capacity of the engine and the size of the vehicle affects the speed of a vehicle [9]. Although van and light truck vehicles have a high engine capacity limit, this type of vehicle is limited to size and weight compared to motorcycle and car. About three quarter of accidents involving motorcycles with other vehicles due to the failure of other vehicle users to detect the presence of motorcycles on the road [12].

Table 6 Chi Square Test between speed limit with vehicle type $(n=1500)$.

\begin{tabular}{ccccc}
\hline $\begin{array}{c}\text { Posted Speed } \\
\text { Limit }\end{array}$ & Vehicle Type & Total \\
\cline { 1 - 3 } Comply & Motocycle & Car & Van / Light Truck & \\
& $343(32.5 \%)$ & $333(31.5 \%)$ & $381(36.0 \%)$ & $1057(100 \%)$
\end{tabular}




\begin{tabular}{ccccc} 
Not Comply $157(35.4 \%)$ & $167(37.7 \%)$ & $119(26.9 \%)$ & $443(100 \%)$ \\
\hline$\left(\chi^{2}=12.327, \mathrm{df}=2, \mathrm{p}=0.002\right)$ & &
\end{tabular}

\section{Conclusions}

The speed of a vehicle is usually controlled by the driver's behavior and obstacles found on the road. Based on the finding, it has shows a positive impact on the speed limit of a vehicle. The speed hump that is effective in reducing the approaching speed of vehicles. Thus, the 3D visual effect speed hump that temporarily installed at selected location are effectively reduce the speed of the vehicle. Whereas, the 3D visual pretended as traffic calming (speed hump) does not give any physical impact to the drive. The effect of the color tone has given perception or imaginations that the road is obstructed and the driver reacts slowly to the vehicle. Furthermore, the frequency of non-stop vehicles at the intersection and ultimately suggestions for the appropriate traffic modulator to reduce vehicle speed at the crossroads of the study can be made.

Authors would like to thanks Registrar Office, UTHM who gave financial support. Also, thanks to Faculty of Civil and Environmental Engineering, UTHM and Smart Driving Research Center (SDRC) for support and providing facilities to accomplish the study.

\section{References}

1. Royal Malaysia Police (PDRM), Statistical report road accidents in Malaysia 2014, Traffic Branch, Police Headquarters, Bukit Aman, Kuala Lumpur, (2014).

2. A.K. Lim, Hubungan Sikap Pengguna Dengan Keterlibatan Dalam Kemalangan Jalan Raya. Universiti Sains Malaysia: Master Thesis, (2007).

3. L. F., Rodriguez, Accident Prediction Models For Unsignalised Intersections. Department of Civil Engineering, The University of Columbia, (1998).

4. G. Alfredo, Traffic Microsimulation Study to Evaluate the Effect of Type and Spacing of Traffic Calming Devices on Capacity. University Polytechnic Spain, (2011).

5. D. Brown, Effective Application of Traffic Calming Technique. Preliminary Investigation. Caltrans Division of Research and Innovation, (2011).

6. R. H. Ewing, Traffic Calming : State of the practice. U.S Department of Transportation, Federal Highway Administration, (1999).

7. M. A. Elliot, V. A. Mccoll, J. V. Kennedy, Road design measures to reduce drivers' speed via 'psychological' process : A literature review (No:TRL564): Transport Research Laboratory, (2003).

8. C. Berthod, Traffic Calming Speed Humps and Speed Cushions. Annual Conference of the Transportation Association of Canada in Edmonton, Alberta, (2011)

9. A. Hazih, Study Effect of Posted Speed Limit on Vehicle Travel Speed Along Federal Route 50(FT050). Universiti Tun Hussein Onn Malaysia: Bachelor Degree Thesis, (2017).

10. M. Z. Ayep, Keberkesanan Penggunaan Bonggol Jalan Bagi Mengurangkan Kelajuan Kenderaan Di Kawasan Sekolah (in Malay). Universiti Tun Hussein Onn Malaysia: Bachelor Degree Thesis, (2014).

11.Pandulaju (2017, Oktober 10). 15 Fakta dan Statistik Mengejutkan Tentang Kemalangan Motosikal. http://pandulaju.com.my/15-fakta-dan-statistik-mengejutkantentang-kemlangan-motosikal/ (Retrieved on 30 November 2017) 
12. S. L. Brown, A. Cotton, Risk mitigating beliefs, risk estimates and self-reported speeding in a sample of Australian drivers. Journal of Safety Research 34 183-188, (2003) 